\title{
Trust in the banking sector: EU experience and evidence from Ukraine
}

\section{Taras Savchenko}

\author{
Dr., Associate Professor, Sumy State University, Ukraine
}

\section{Levente Kovács}

Dr., Associate Professor, University of Miskolc, Poland

(C) The Authors, 2017. This article is published with open access at ARMG Publishing.

\begin{abstract}
This work presents the results of the investigation of trust to banks in European Union as well as in Ukraine. The special focus was on relevant documents that describe the strategic directions of the Ukrainian banking system's future development in the context of restoring trust to banks. Furthermore, some of the quantitative results of the authors' previous publications are summarized, as they may prove valuable in the study of the subject.

The authors concluded that the recent crisis is a stark reminder that banking functioning based on trusting. The dramatic changes in the banking environment brought about by financial innovation and technological progress have not diminished the role of trust in banking. Any lack of trust significantly impairs the functioning of the banking sector and prevents banks from contributing to economic growth.
\end{abstract}

Keywords: bank, central bank, monetary policy, trust in banks.

JEL Classification: E52, E58, G21.

\section{Introduction}

Trust is a core feature of any banking industry. Without it, commercial banks as well as central banks could not be successful in achieving their goals.

In terms of the placement of money, bank-client relationships allow for two directions. In one direction the bank accepts a deposit from the client, and in the other the bank grants a loan to the client. Both directions rely on trust invested in the other party, since, in the future, the client who made the deposit wishes to regain his or her money with interest. For this, he or she will look for a well-capitalized bank with a good reputation in the market i.e. one that the general public considers to be a safe and dependable institution with liquidity over the long term, where personal contact and/or electronic communication is consistently reliable, and where the bank offers investment opportunities holding out the promise of a yield and risk acceptable to the investor. As for the other direction, the bank's management handles the received deposits and the bank's capital well if it manages to do so in a way that promises positive returns. In the case of a loan, this means that the client has a business plan and business management skills offering reasonable assurance that he or she will repay the loan in the future. Repayment risks are mitigated through the use of collateral.

The authors propose to investigate three main elements of trust in banks: transparency, quality of legislation and empirical credibility. Transparency is often regarded as a precondition for trust, while the quality of legislation expresses the effectiveness of the state in this matter. Empirical credibility describes the actual level of trust consumers have for banks in Ukraine - reflecting, in other words, the grade of implementation of the two elements of trust mentioned above.

Today, transparency has become a key feature of both the banking industry and monetary policy making. For this reason, commercial and central banks worldwide consider transparency a very important factor in their success. Bank's management and board must have a sense of responsibility for developing the bank's individual risk culture, thus enabling it to deal with risk in a way that supports this long-term business perspective and fosters transparency and accountability. Bank requires well-functioning communication mechanisms and IT systems to link the bank's decision-making, risk management and control organs together, to convey information to where it is needed, and to help create awareness and transparency about the bank's objectives, policies and values throughout the organization. 
On the one hand, a number of empirical studies show that there is a continuous process of improvement in the transparency levels of both commercial and central banks in Ukraine. The loss of Ukrainian banks' transparency during the global financial crisis was observed to be only temporary (Savchenko, T., Zakutniaia, A. 2016). Some of quantitative results on transparency issues are considered in the next part of this work. Furthermore, the quality of national legislation is satisfactory with respect to maintaining consumer trust in Ukrainian banks. This positive conclusion is based on expert examinations (Mylovanov et al. 2016) of the two main laws concerned (The Law of Ukraine on Banks and Banking, and The Law of Ukraine on the National Bank of Ukraine), with both containing internationally recognized approaches to the regulation of the banking industry and the functions of the central bank. The full texts of these laws are available in English on the official website of the National Bank of Ukraine (hereinafter - NBU, see NBU 2000; NBU 1999).

On the other hand, however, it is obvious that there is a low level of trust in Ukrainian banks among consumers. According to surveys conducted by the Center for Social Monitoring and the Institute of Sociological Studies, about 70 percent of citizens do not trust banks today (Ukraine Crisis Media Center 2016). The German Society for Consumer Research (GfK) estimation ${ }^{1}$ is even worse: only about $10 \%$ of Ukrainian citizens trusted banks in September 2016, while in previous periods, the levels were as follows: March $2015-11.6 \%$, September $2015-13.0 \%$, March $2016-11.9 \%$. Thus, there is a considerable disparity between transparency and quality of legislation, on the one hand, and the level of actual empirical credibility on the other. Therefore, the aim of this paper is to conduct a comprehensive analysis of the causes of consumer distrust in Ukrainian banks, and to determine possible pathways to recovering that trust.

\section{Literature review}

Numerous researchers have analyzed the question of trust in the economic relations between banks and their clients. Most of them investigate factors of client trust with respect to a wide range of bank products and technologies. For example, Gill et al. (2006) examine the impact of some personal qualities related to the provision of banking services to customers - including empathy, kindness and others - and their relation to the parameters of the provision of actual banking services. The results identify six factors that generally support confidence, and the authors suggest that the influence of the different factors varies during particular periods of the bank-customer relationship.

History tells us that trust is one of the most essential pillars of a sound banking system. However as shown above, trust requires the simultaneous presence and fulfilment of several factors and conditions: positive performance in the past, good reputation, stability, profitability, solid ownership structure, capitalization above the minimum requirement, reliable operation, provision of good quality services, quality contact with clients, and sufficient visibility in the market. While building up trust takes years and often decades, it can be lost in a matter of days (Narayan, 1952). In the banking sector, the loss of trust typically leads to certain bankruptcy and the winding up of the institution.

There are several articles that are closely related to the present study, as they are directed toward researching trust in banks as specialized financial institutions. Knell and Stix (2009) describe the reasons behind the decline in trust in Austrian banks during the global financial crisis, while making an assessment of the factors that determine the level of trust in banks. In this case, the authors find that the extension of deposit insurance coverage in October 2008 had a positive effect on trust. Furthermore, they show that trust in banks is mainly affected by "subjective" variables such as the consumer's assessment of the current economic and financial situation. Among their central "subjective" variables, the authors consider several proxies related to the financial situation of the household, bank customers' perceptions of their own economic future, and perceptions of inflation and Euro currency stability.

Mosch and Prast (2008) provide evidence regarding trust in banks in the Dutch financial sector. Based on surveys carried out in the period 2003-2006, the authors find a significant positive association between confidence in the economy and trust in the country's institutions.

Spanish researchers Carbó-Valverde et al. (2013) analyze the extent to which bank customers' perceptions of several bank attributes foster trust in banks. They also study the extent to which a potential loss of trust in banks due to a financial crisis can be offset by improvements in bank customers' perceptions of such attributes.

\footnotetext{
${ }^{1}$ Data were obtained from the GfK staff as a response to the authors' request made through the official website: http://www.gfk.com/uk-ua/.
} 
Lebedyev (2011) describes individuals' characteristics that strongly influence their trust in banks, including: place of residence, trust in deposit insurance funds, and awareness and availability of information on financial markets. Age, education and income variables are found to only marginally affect trust in privately owned banks.

The above-mentioned results are primarily aimed at the investigation of the banking systems of developed countries. However, there is a shortage of comprehensive studies pertaining to trust in the banks of developing countries, such as Ukraine.

\section{Methodology}

In the present research, the authors proposed that the questions under consideration could be investigated precisely using normative and positive approaches to analysis. Normative methods of economic research express normative judgments about the outcome of the economy, or the goals of public policy (i.e. answering the question of "what situation ought to be"). On the other hand, positive analysis focuses on facts and the explanation of economic phenomena by testing economics theories (or answering the question of "what is the status quo").

The normative analysis is based on a brief overview of the main documents in which the matters of the trust to banks have been considered, including:

$>$ the guidelines of the EU Financial Stability Board on supervisory interaction with banks on risk culture;

$>$ EU's Single Supervisory Mechanism (SSM);

$>$ documents on regulation, supervision and risk management of the banking sector that were developed by the Basel Committee on Banking Supervision (Basel II, Basel III);

$>$ the Memorandum of Cooperation with the International Monetary Fund;

$>$ the Comprehensive Program of the Ukraine Financial Sector Development until 2020;

$>$ the National Bank of Ukraine Monetary Policy Guidelines for the years 2016-2020.

The positive analysis focuses on certain quantitative results concerning the restoration of trust in banks in Ukraine. In the first stage, we investigated Hungarian experience in promoting financial literacy (using panEuropean Money Week framework) as a foundation of trust in bank sector. In the second stage the ongoing general trends of the development of the Ukrainian banking system were investigated using key statistical data, such as Financial Stability Reports, the Ukrainian Lending Survey and a Business Outlook Survey. The surveys were conducted by the National Bank of Ukraine. In the third stage of the positive analysis, the main results of the authors' previous investigations were examined - results that provided evidence on the question under consideration, including:

$>$ approaches to the development of explicit monetary rules;

$>$ bank transparency issues;

$>$ the impact of credit information on the robustness of banks.

\section{Normative analysis}

In the aftermath of the crisis, significant changes have been made in the EU regulatory and supervisory framework. Reforms of capital and liquidity regulation, risk management, governance and resolution regimes have been introduced. Moreover, consumer protection has been enhanced. The regulatory framework now has a better and broader base, and is less vulnerable to arbitrage.

While much has been achieved, We would like to highlight one piece of work in particular. Last year, the Financial Stability Board published a set of guidelines on supervisory interaction with banks on risk culture. The guidelines are aimed at assisting supervisors in their assessment of risk culture by listing a number of indicators or practices that can be indicative of an overall sound and well-balanced approach. These include an appropriate "tone from the top" within a bank and other key factors, such as accountability, effective internal communication, the existence of challenge mechanisms within the decision-making process, and incentives for employees.

Supervisors themselves have also changed since the crisis. They are now stricter, more proactive and assess banks in a much more holistic way. Topics such as governance, remuneration and risk appetite are among the key priorities on every supervisor's agenda this year. 
In the Single Supervisory Mechanism (SSM) for example, the European Union in the final stages of a thematic review of governance and risk appetite in the 123 institutions directly supervised by ECB which will feed into this year's assessments of the capital and liquidity adequacy of banks. Our initial findings indicate that a number of banks, while meeting national requirements, do not comply with internation al best practices with regard to governance. Our key observations include examples of power concentration in individual board members (e.g. holding multiple offices or chairmanships within the same group), a lack of separation between a bank's risk and audit functions, information asymmetries among board members, and instances where the board simply does not take enough time to discuss and reflect on individual issues. It is also apparent that some banks are still in the early stages of implementing their risk appetite framework and therefore still have a lot of work to do to ensure its consistent application throughout the entire organization.

The bank's capital provides the collateral for client deposits and could be treated as one of the key trust factor for depositors. Each EU country has a minimum capital requirement (usually amounting to millions of euros). The bank's management and employees represent business management know-how. Professional experience and university education are prerequisites for the appointment of a bank leader, and banking supervision makes sure that these rules are enforced. Keeping market risk low (to guarantee that the members of the banking sector maintain their stability and liquidity positions) is ensured through international, EU and local regulations. Of all the regulations applying to the banking sector the Basel requirements are the most well known.

The Basel Convention was adopted in 1988 and set the minimum capital requirement for internationally active banks. The Basel II accord set the operational risk capital requirement, supervisory processes and rules for data disclosure. Basel III (introduced in response to the economic crisis) increased the level and quality of capital as well as liquidity requirements. While Basel III will not be fully in force for another three years, its "successor" already ranks high on the list of things that keep global bank CEOs awake at night. As a minimum, rules concerning risk weighted assets (RWA) and total loss-absorbing capacity (TLAC) requirements are likely to be changed and implemented.

Also we examined some documents related directly the Ukrainian banking sector. Taking into account the statement made above about the satisfactory examination of the two main special laws pertaining to the Ukrainian banking industry, documents were considered that established practical approaches to the implementation of the mechanisms contained in those laws. Furthermore, it must be emphasized that the documents often referred directly to trust problems.

Representatives of Ukraine that developed the Memorandum of Cooperation with the International Monetary Fund (Ukraine and the IMF 2016) declare that Ukraine has continued to make steady progress in implementing its banking sector strategy to rehabilitate the financial sector and restore confidence. The main results of banking sector reform are mentioned in the confirmation of this declaration. Firstly, the final results of the second wave of bank diagnostics and NBU's verification of related-party loans for the 20 largest banks were reported to each banking institution. Secondly, the NBU has completed its review of the recapitalization plans submitted by 16 of the 20 largest banks. (In 2017 the National bank will carry out diagnostics on the next 40 banks. Thus, NBU will have a detailed analysis of the assets of the 60 banks that make up, in total, more than $97 \%$ of the Ukrainian banking sector). Thirdly, the NBU has completed eight targeted inspections of banks to address the risks of misuse by corrupt officials. The inspections focused on the regulatory requirements related to customer due diligence and politically exposed persons, and it will publish on an ongoing basis any sanctions imposed for banks' breaches of AML requirements.

The next document under consideration is the Comprehensive Program of the Ukraine Financial Sector Development until 2020 (NBU 2015a). The authors of this program argue that financial sector development during the period 2009-2014 was discrete and disproportionate in nature. The development of the financial sector during that period was complicated by the lack of effective legislation and prudential supervision, which led to a significant number of captive financial institutions and so-called "financial pyramids", and thus to a deepening crisis of distrust in the financial sector. Therefore, further development in the financial sector must be based on suitable principles, including those that support trust recovery: European integration; transparency and high standards of information disclosure by financial intermediaries and regulators; and responsibility and trust between financial-sector participants and regulators. 
Finally, this study investigates the NBU Monetary Policy Guidelines for the period 2016-2020 (NBU 2015b). In light of the strong consensus in the literature that low and stable inflation is the one of the main requirements for sustainable economic growth that can be delivered by a central bank, the NBU declared itself to be committed to the cause of lowering inflation. The medium-term target for inflation is set at $5 \%$ (i.e. for the annual increase in the consumer price index) for the 2016-2020 period, and will be achieved gradually. In particular, the short-term targets for the annual increase in CPI will be as follows: December 2016: $12+/-3 \%$; December 2017: 8 +/- 2\%; December 2018: 6 +/- 2\%; December 2019 and after: $5+/-1 \%$.

The authors of the NBU guidelines argue that for decades, the Ukrainian economy has suffered from volatile and unpredictable inflation that has undermined trust in the UAH, while causing the following:

$>$ high interest rates on deposits and loans;

$>$ incentives for dollarization as a natural hedge for depositors;

$>$ impediments for economic growth due to the unstable business environment.

Consisting of a set of practices for implementing a rule-based approach with high levels of accountability and a transparent monetary policy, the inflation-targeting framework would seem the most suitable prospective regime for Ukraine in its aspiration to restore trust in its banks - as well as in solving other problems in the Ukrainian financial sector.

\section{Positive analysis}

5.1. Hungarian experience in promoting financial literacy. Since financial literacy reduces the asymmetric information in relations between bank and its client and raises level of predictability of the households' behavior, the financial literacy could be considered as a core factor of trust in bank.

According to the Organization for Economic Co-operation and Development (OECD), whose findings are confirmed also by recent surveys, our society faces worrying low levels of youth financial literacy and in many cases, significantly lower levels than previous generations. On the other hand, it is almost impossible to insert the development of financial literacy into traditions-based school teaching as a new subject of study, the focus is on organizing thematic days or weeks. The holding of thematic days is known at the international level as well, so that the introduction of a Global Money Week (GMW) presented no great difficulty.

GMW is an annual global celebration, initiated by Child \& Youth Finance International, with local and regional events and activities aimed at inspiring children and youth to learn about money, saving, creating livelihoods, gaining employment and becoming an entrepreneur. Previous 2016 Global Money Week has reached 7 million children \& youth, 132 countries, 13.950 organizations, over 33.278 activities.

Among the efforts of national banking associations, those of the Hungarian Banking Association stand out, since close to one-third of the 300-350.000 students reached through classroom training organised within the framework of the pan-European Money Week were Hungarian. For this reason it is worth presenting the events in Hungary in 2015 and 2016.

\section{Events in Hungary in 2015}

The Hungarian Banking Association, in cooperation with the Pénziránytü Foundation, the Ministry of Human Capacities responsible for education, and the Hungarian Institute for Educational Research and Development, worked out a lesson plan and teacher's guide for a professional lesson for three age groups (grades 3-4, 5-8 and 9-12). The topic chosen for this year was the family budget. Animations were also made to elaborate on the theme, based on the messages "Money doesn't grow on trees!" for children in grades 3-4, "Great oaks from little acorns grow!" for grades 5-8, and "You reap what you sow!" for secondary school students. Some 660 schools answered the Money Week summons. Lessons in financial literacy were taught by 1,000 teachers and 200 voluntary financial experts - among them the Minister for National Economy - with a total of 90.000 students taking part in this thematic instruction. Follow-up surveys highlighted one deficiency: the 45-minute lessons were too short.

An adventure game on Facebook, the social network favoured by young people, offered a seven-mission financial adventure tour, in which 3.253 registered individual players and 371 school groups took part. 
The media also provided exhaustive reporting of the events of Money Week, as a result of which the press coverage of the opening event was very favourable indeed, consisting of 60 significant written and online appearances, five TV reports with national coverage, as well as one national and one regional radio report.

\section{Events in Hungary in 2016}

Programmes were further developed based on the experiences of the preceding year. In this way, topics for school teaching were broken down into four age groups: grades 3-4, 5-6, 7-8 and 9-12. Lesson plans and teacher's guides were drawn up for three 45-minute lessons. The motto was "Knowledge pays interest!", while topics drew attention to financial planning and frugal saving. Ministerial support strengthened, thanks to which a total of 1.435 teachers and 250 volunteers delivered the three-part lecture series to 102.000 students in 788 schools. The emphasis this year was again placed on preparing teachers, as this is one of the guarantees of successful and productive knowledge transfer.

The National Bank of Hungary, the Hungarian Banking Association and the Pénziránytü Foundation, the latter established by student loan provider Diákhitel Zrt., played vital roles in the activities of Money Week in Hungary. The textbook "Iránytü a pénzügyekhez" (Finance Compass) was created with the latter's support, which conforms to ministerial decrees on education. The textbook, aimed at students in grades 9-10, deals in 65 chapters with the topics of "Our everyday finances" and "Living in a market economy" through the everyday activities of an average family. In keeping with durable textbooks in Hungary (usable over several years), the book was published in hardback in 40.000 copies. Based on feedback from students and teachers, the textbook is practically oriented, contains exciting stories, is easy to learn and is built on an up-to-date curriculum.

Media appearances were also satisfactory in 2016, with four national TV channels, two national and two regional radio stations, and some 60 significant written and online press sources reporting on the events of Money Week.

The comprehensive analysis of the financial literacy issues has been presented in the book (Kovács Levente and Terták Elemér, 2016).

5.2. General trends of development of the Ukrainian banking system. In June 2016, the National Bank of Ukraine published the first issue of the Financial Stability Report (NBU 2016a), in which it presented some evidence of the restoration of trust in Ukrainian banks, namely that an increase in retail deposits in UAH has been observed since April 2015, and that FX deposits have been growing since December 2015. The NBU expects the trend to continue till 2017 , and banks' deposit base to increase by $10 \%$ in total.

Furthermore, NBU staff point out that the rebalancing of commercial banks' resource base will take several more years. In the future, banks will rely less on wholesale funding, focusing instead on deposits from corporate clients and households. The increase in the retail deposits of banks is evidenced by the banks' key performance indicators shown in Table 1. However, objective investigation of the data in the table gave the authors of this research cause to conduct further, enhanced analysis. While the banking system is in the initial stages of a slow recovery, many negative trends are still evident.

Based on the indicators in Table 1, trends were divided into two groups, taking into account their influence on trust in banks. The following tendencies were regarded as positive:

1. A declining number of licensed banks (as of late July 2016, 79 banks, accounting for about $30 \%$ of system assets, have been withdrawn from the market as part of efforts to strengthen and consolidate the financial system).

2. A growing share of foreign capital in the authorized capital of banks (in the third quarter of 2016, the share of foreign capital exceeded the $50 \%$ level for the first time).

3. After declining twice in the period 2014-2015, the equity of banks increased rapidly in 2016, leading to growing regulatory capital adequacy, or "H2". (The NBU has completed its review of the recapitalization plans submitted by 16 of the 20 largest banks that require additional capital, and is currently monitoring the implementation of the 14 approved plans). 
Table 1. Key performance indicators of Ukrainian banks, UAH millions, 2008-2016

\begin{tabular}{|c|l|c|c|c|c|c|c|c|}
\hline No. & \multicolumn{1}{|c|}{ Indicators } & 01.01 .2008 & 01.01 .2010 & 01.01 .2012 & 01.01 .2014 & 01.01 .2015 & 01.01 .2016 & 01.08 .2016 \\
\hline 1 & $\begin{array}{l}\text { Number of licensed } \\
\text { banks }\end{array}$ & 175 & 182 & 176 & 180 & 163 & 117 & 101 \\
\hline 2 & $\begin{array}{l}\text { Share of foreign cap- } \\
\text { ital in the authorized } \\
\text { capital of banks, } \%\end{array}$ & 35 & 35.8 & 41.9 & 34 & 32.5 & 43.3 & 53.3 \\
\hline 3 & Banks' assets & 599396 & 880302 & 1054280 & 1278095 & 1316852 & 1254385 & 1260827 \\
\hline 3.1 & $\begin{array}{l}\text { Amounts due from } \\
\text { the NBU }\end{array}$ & 19120 & 23337 & 31310 & 47222 & 27554 & 27392 & 42656 \\
\hline 3.2 & Loans granted & 485368 & 747348 & 825320 & 911402 & 1006358 & 965093 & 910804 \\
\hline 3.3 & $\begin{array}{l}\text { Share of Non Per- } \\
\text { forming Loans in to- } \\
\text { tal loans, } \%\end{array}$ & 1.3 & 9.4 & 9.6 & 7.7 & 13.5 & 22.1 & 26.1 \\
\hline 3.4 & $\begin{array}{l}\text { Provisions against } \\
\text { asset-side operations }\end{array}$ & 20188 & 122433 & 157907 & 131252 & 204931 & 321303 & 311416 \\
\hline 4 & Liabilities, total & 599396 & 880302 & 1054280 & 1278095 & 1316852 & 1254385 & 1260827 \\
\hline 4.1 & Equity & 69578 & 115175 & 155487 & 192599 & 148023 & 103713 & 147937 \\
\hline 4.2 & Banks' liabilities & 529818 & 765127 & 898793 & 1085496 & 1168829 & 1150672 & 1112891 \\
\hline 4.2 .1 & $\begin{array}{l}\text { Amounts due to indi- } \\
\text { viduals }\end{array}$ & 163482 & 210006 & 306205 & 433726 & 416371 & 389060 & 398927 \\
\hline & $\begin{array}{l}\text { of which: time depos- } \\
\text { its from individuals }\end{array}$ & 125625 & 155201 & 237438 & 350779 & 319121 & 281462 & 287812 \\
\hline 5 & $\begin{array}{l}\text { Regulatory capital } \\
\text { adequacy (H2), } \%\end{array}$ & 13.92 & 18.08 & 18.9 & 18.26 & 15.6 & 12.74 & 14.09 \\
\hline 6 & Financial results & 6620 & -38450 & -7708 & 1436 & -52966 & -66600 & -9266 \\
\hline
\end{tabular}

Source: compiled by the authors based on official information from the National Bank of Ukraine: https://bank.gov.ua/control/en/publish/article?art_id=34705283\&cat_id=34798612.

The trends that indicate distrust in banks are as follows:

$>$ An ongoing tendency toward decreasing the number of loans granted, indicating the high lending risks constraining the normalization of the functioning of the banking sector. This trend is further evidenced by the stable growth of the share of overdue loans as a proportion of total loans (during the past three years, this indicator has increased threefold).

$>$ In spite of the growth in retail deposits, total banks' liabilities are still decreasing.

$>$ The Ukrainian bank system has incurred losses during the last three years, though the growth rate of negative financial results decreased sharply in 2016.

These findings on the complicated and scarcely predictable trends in the Ukrainian banking system are confirmed by the expectation surveys performed by the National Bank of Ukraine. The Ukrainian Lending Survey (NBU 2016b) assesses the state of the credit market in Q2 2016, and shows respondents' (i.e. the managers of 66 banks, which together account for $96 \%$ of the banking system's total assets) expectations over the next 12 months, including that A) banks expect corporate lending to decrease and retail lending to increase; while B) as before, most banks expect deposit growth, and especially in the corporate segment.

The Business Outlook Survey (NBU 2016c) reflects the opinions of the respondents (in this case, the heads/managers of Ukrainian enterprises). Respondents upgraded their expectations about both the economic situation in Ukraine and the prospects for the development of their enterprises over the next 12 months, expecting:

Growth in the output of goods and services in Ukraine.

$>$ A significant slowdown in consumer price growth rates to $18.9 \%$ (down from $22.2 \%$ in Q1 of 2016).

$>$ Higher business activity and, thus, higher borrowing requirements.

According to the respondents, the unstable political situation and excessive energy prices were the main negative factors hampering enterprises' growth.

To summarize the general trends of the development of the Ukrainian banking system in terms of trust recovery, a question should be considered about the role of the new team that has been in charge of the NBU since 
2014. Because of the general financial and macroeconomic problems Ukrainians have faced in recent years, there are many negative opinions in the general population about NBU top management. However, an objective view should take into consideration all of the circumstances experienced in that period. Perhaps the most balanced appraisal was made by a number of Ukrainian experts from the VoxUkraine editorial board (namely Tymofiy Mylovanov, PhD, University of Pittsburgh; Yuriy Gorodnichenko, Ph.D., University of California Berkeley; Oleksandr Zholud, Senior Economist, International Center for Policy Studies; and Olena Bilan, Chief Economist, Dragon Capital) in their recent publication (Mylovanov et al., 2016):

"The National Bank of Ukraine faced some of the toughest possible challenges in 2014-2015. There was no easy solution to the problems that had accumulated over many years. The menu of options was very limited. The "medicine" had to be painful. Blaming the Gontaryeva (Valeriya Gontaryeva is the current Chairwoman of the National Bank of Ukraine) team for administering a bitter "pill" is not fair. Perhaps some details of what the NBU did during the crisis could have been better (e.g. let the hryvnia float and impose capital controls earlier) and some critique may be justified. But more importantly, the critics offer no feasible alternative strategies for handling the crisis. The course taken by the NBU was a reasonable policy given the circumstances."

5.3. Evidence from the authors' previous investigations. Analysis of approaches to the development of explicit monetary rules. Taylor (1999) defines the monetary policy rule as a description (expressed graphically or by a formula) of a method for the use of monetary policy instruments, such as a monetary base rate or federal funds rate, depending on the dynamics of the economic parameters.

For Ukraine, one of the means of improving the transparency and credibility of NBU policy is to use explicit monetary rules. The central bank should find a balance between discrete measures and monetary rules in its implementation of monetary and communication policies. During the modeling of the monetary policy, the National Bank of Ukraine implicitly applied a modified Taylor rule over an extended period. However, the present research emphasizes the need to develop a simplified and explicit policy rule. The introduction of an explicit rule would make it possible to benefit from its direct use, and not just as one of the forecasting equations.

The choice of the monetary rule's basic form should be based on relevant international experience. The main problem in determining the rule's basic form is the choice of the key instrument of the monetary policy. The results of the examination of international experience led to the conclusion regarding the appropriate use of monetary rules for central bank's determination of basic interest rates. However, researchers note that given inefficient performance of the interest rate channel mechanism of transmission, a monetary rule can be developed to determine an equilibrium (optimal) level of the monetary aggregates concerned.

Most of the researchers come to the same conclusion regarding the minimal impact of the NBU on inflation when using the instruments of interest rate policy during the period 2000-2014. In the period 2014-2016, the IMF and the NBU made efforts to increase the efficiency of the interest rate channel monetary policy mechanism. However, it is not yet possible to estimate precisely how successful these changes have been. At the current stage of development of monetary policy in Ukraine, it seems useful to investigate both approaches to develop a monetary rule - for money aggregates as well as for the main interest rate.

Initially, this research examined monetary policy rules for monetary aggregates based on the form proposed by McCallum (1988). This rule is the result of the dialectical development of Friedman's money supply rule. Several changes were made regarding the McCallum's basic approach. One of them was to apply the modified Hodrick-Prescott filter proposed by Hyeongwoo (2004) for the estimation of the equilibrium trend of nominal and real GDP (Figure 1, see in Appendix). This approach is also used by the World Bank.

The next step was constructing a regression model (for McCallum variables) with inflation lag in the first quarter, though the inflation coefficient remains insignificant. The use of other lags at economically substantiated intervals did not improve the model. It is likely that the insignificant influence of the consumer price index on the dynamics of the money supply can be explained by the fact that the analysis was conducted during the period from 2004-2011, when the main priority for the NBU was to ensure exchange-rate stability while the main channel for increasing the money supply was currency interventions in the interbank market. Therefore, this research withdrew inflation from the regression model in order to improve its quality.

Thus, the following regression model was proposed in Equation 1:

$$
\Delta m=0.16-1.10 \Delta v+0.87\left(\Delta x-\Delta x^{*}\right)+1.87 \Delta q^{*},
$$


where $\Delta m$ is the growth in money supply (M3 aggregate); $\Delta v$ is the growth in money turnover; $\Delta x$ is the growth of nominal GDP; $\Delta x^{*}$ is the growth of equilibrium nominal GDP; and $\Delta q^{*}$ is the growth of equilibrium real GDP.

The regression statistics for this model are shown in Table 2. Analyzing the data, it could be concluded that the model was statistically significant $(\alpha=0.05$ ), and that all coefficients of the model were also significant. The analysis of the correlation matrix led to the conclusion about the lack of multicollinearity. Therefore, it could be concluded that the multivariate model had a sufficient quality, and could be used to analyze the relationship between its indicators as well as in forecasting.

Table 2. Static characteristics of multivariate regression in equation 1

\begin{tabular}{|c|c|c|c|c|c|c|}
\hline Indicators & \multicolumn{6}{|c|}{ Values of indicators } \\
\hline \multicolumn{7}{|c|}{ Regression statistic } \\
\hline Multiple $R$ & \multicolumn{6}{|c|}{0.947560663} \\
\hline$R^{2}$ & \multicolumn{6}{|c|}{0.897871211} \\
\hline Adjusted $R^{2}$ & \multicolumn{6}{|c|}{0.887658332} \\
\hline Standard error & \multicolumn{6}{|c|}{0.055351462} \\
\hline Observations & \multicolumn{6}{|c|}{34} \\
\hline \multicolumn{7}{|c|}{ Analysis of variance } \\
\hline & $d f$ & $S S$ & $M S$ & $F$ & $F$-statistic & \\
\hline Regression & 3 & 0.808063173 & 0.269354391 & 87.91558349 & 5.84102E-15 & \\
\hline Residual & 30 & 0.091913531 & 0.003063784 & & & \\
\hline Total & 33 & 0.899976704 & & & & \\
\hline \multicolumn{7}{|c|}{ Characteristics of indicators } \\
\hline & Coefficients & Standard error & $y$-statistic & $p$-value & Lower 95\% & Upper $95 \%$ \\
\hline$Y$-intercept & 0.161956023 & 0.014760621 & 10.97216892 & $5.05071 \mathrm{E}-12$ & 0.1318108 & 0.1921012 \\
\hline Variable $X_{1}$ & -1.100720162 & 0.142283919 & -7.736082664 & $1.24649 \mathrm{E}-08$ & -1.3913026 & -0.8101376 \\
\hline Variable $X_{2}$ & 0.871250518 & 0.091066531 & 9.567186878 & $1.26906 \mathrm{E}-10$ & 0.6852678 & 1.0572332 \\
\hline Variable $X_{3}$ & 1.865530251 & 0.406867894 & 4.585100661 & 7.49785E-05 & 1.034595 & 2.6964653 \\
\hline
\end{tabular}

Source: compiled by authors.

Thus, the importance of developing an explicit monetary rule for the money supply of the Ukrainian economy has been substantiated (if, for example, the interest rate channel mechanism of monetary policy is inefficient), and the stages of its development have been studied. These results are more deeply considered in the author's previous work (Savchenko and Kozmenko, 2013).

An alternative approach to the development of the explicit monetary rule is associated with the assessment of the equilibrium trend of the basic interest rate of the NBU. To achieve this goal, coefficients were used that had been substantiated by the researchers of monetary rules. The results of the calculations are shown in Figure 2 (see in Appendix).

This figure demonstrates the optimal trajectories of the basic monetary policy rates of the NBU, which are calculated for the credit spread and the government bond spread. As can be seen, these trajectories are quite similar: the correlation coefficient is 0.8 . It also shows the trajectories of the smoothed discount rate and the refinancing rate, which also have similar dynamics. In addition, the graph depicts the actual refinancing rate - the values of which normally vary within the corridor formed by the smoothed refinancing rate (close to the upper limit) and the discount rate (lower limit).

Analysis of Figure 2 led to the following conclusions: During 2004 and the first half of 2007, the use of the interest rate as a lever of monetary policy was economically justified. However, since the second half of 2007, the conditions were suitable for raising the refinancing rates in order to introduce elements of preventive restrictive policy in an effort to produce a counter-cyclical effect and prevent the economic system's overheating. Starting from the fourth quarter of 2008, which was characterized by the significant influence of the global financial crisis on the Ukrainian economy, the trajectory of optimal rates is significantly lower than the actual rates of the NBU. During the period 2010-2011, the interest rates of the NBU were economically justified. Since the first quarter of 2012 until the end of the study period (Q1 of 2014), the economically justified 
central bank rates should have been much lower than their actual levels. This was due to the need to supply the economy with cheap monetary resources to support economic activity in the wake of the crisis period. Findings on the interest rate monetary rule for the Ukrainian economy are shown in Savchenko et al. (2014).

Investigation of bank transparency issues. The completeness and timeliness of the information provided by central banks determines the direction of economic decisions of individuals and entities, which form the dynamics of macroeconomic indicators and determine the level of trust in monetary policy. During 2014-2016, the NBU implemented a number of projects that will contribute to a significant increase in its level of transparency, and which will provide a reliable basis to ensure the necessary level of efficiency in achieving inflation targets. This conclusion is confirmed by the calculation of the transparency index (Figure 3), which compares previous results (Savchenko and Zakutniaia 2016) with the results of Dincer and Eichengreen (2013).

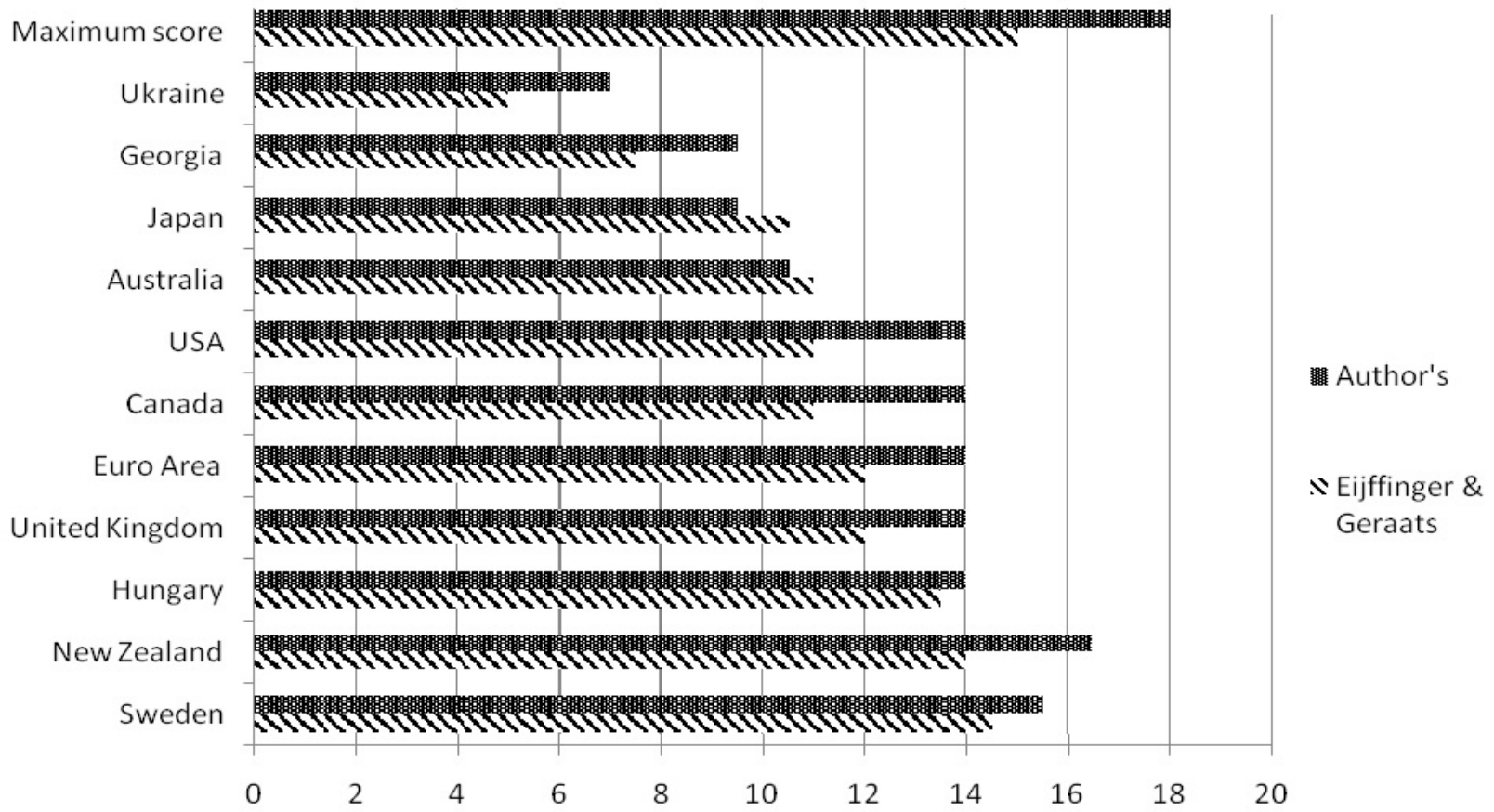

Figure 3. Comparison of the results of Dincer and Eichengreen approach with the authors results

Source: compiled by authors.

Differences in the study periods should be taken into account, along with the relevance of the authors' previous results from the second quarter of 2015, and the transparency index. The results presented by Dincer and Eichengreen (2013) cover data up to the end of 2010. Thus, the dynamics of transparency can be estimated, and explained by two factors: 1) The changes in 15 indicators (which are analyzed in a similar method) over the last five years; 2) The consideration of three additional parameters proposed by the authors that automatically lead to an increase (in the case of a positive evaluation) of the number of points for the present methodology. One of the three additional parameters proposed in the aformentioned paper is the use of internet channels by central banks to increase the level of monetary policy transparency (Table 3). After analyzing data from the table, it should be noted that all central banks use some Internet channels. The most popular are: Twitter, YouTube, RSS feeds, E-mail, and videos.

Table 3. Analysis of modern Internet communications used by central banks of leading countries and the NBU

\begin{tabular}{|c|c|c|c|c|c|c|c|c|c|c|c|c|}
\hline & 离 & $\begin{array}{l}\stackrel{0}{\Xi} \\
\stackrel{\Xi}{\Xi} \\
\stackrel{\partial}{\Xi}\end{array}$ & 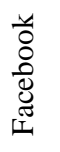 & $\frac{\vec{t}}{\frac{\overrightarrow{0}}{I}}$ & 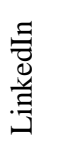 & $\begin{array}{l}\tilde{D} \\
\stackrel{d}{\Delta} \\
\tilde{n} \\
\tilde{n} \\
\sim\end{array}$ & : & $\begin{array}{l}\tilde{d} \\
\stackrel{d}{0} \\
:\end{array}$ & $\underset{\tilde{z}}{\stackrel{0}{z}}$ & 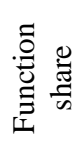 & $\begin{array}{l}\frac{1}{0} \\
\frac{0}{0} \\
\frac{0}{0} \\
\frac{0}{2}\end{array}$ & $\underset{\tilde{U}}{\tilde{U}}$ \\
\hline Australia & + & + & & & + & + & + & + & & & & \\
\hline Canada & + & + & & + & + & + & + & + & & + & & \\
\hline United Kingdom & + & + & + & + & + & + & + & + & + & + & & \\
\hline Belgium & + & + & & + & & + & + & + & & & + & \\
\hline
\end{tabular}


Table 3 (cont.). Analysis of modern Internet communications used by central banks of leading countries and the NBU

\begin{tabular}{|c|c|c|c|c|c|c|c|c|c|c|c|c|}
\hline & 离 & 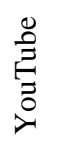 & 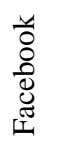 & 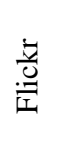 & 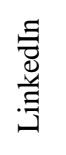 & 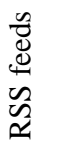 & 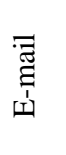 & 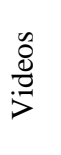 & 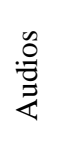 & 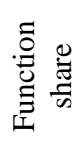 & $\begin{array}{l}\frac{1}{0} \\
\frac{0}{2} \\
\frac{0}{0} \\
\frac{0}{\infty} \\
\frac{0}{2}\end{array}$ & 胥 \\
\hline Sweden & + & + & + & & + & + & + & + & & + & & + \\
\hline USA & + & + & + & + & + & + & + & + & & & + & \\
\hline Eurozone & + & + & + & + & + & + & + & + & & + & & \\
\hline Hungary & & + & + & & & + & + & + & & & & \\
\hline Ukraine & + & & + & + & & + & + & + & & & & \\
\hline Georgia & + & + & + & + & & + & + & + & & & & \\
\hline New Zealand & + & + & + & & & + & + & + & + & + & & \\
\hline Japan & + & & & & & + & + & + & & & + & \\
\hline
\end{tabular}

Source: compiled by the authors based on data from official websites of central banks (with cut-off date 26.01.2016).

Comparative analysis of the information disclosed by central banks (Figure 3) shows a constant improvement in monetary policy transparency. As can be seen, 8 of 11 central banks have increased the transparency level of their activities in general and of their monetary policy in particular. The central banks of Japan and Australia have shown a negative trend, however.

The impact of credit information on the robustness of banks. One of the most important factors or qualities in a credit portfolio is that of banking system reliability. It is obvious that there is a direct relationship between this indicator and trust in banks. In turn, the quality of the loan portfolio depends on many factors that are investigated by researchers. In a previous paper (Savchenko and Bielova, 2016), a group of credit-risk factors are focused upon that are related to the availability of information about the borrower.

In this analysis, an algorithm is used that consists of three successive stages. Firstly, a cluster analysis was conducted using STATISTICA software to form homogeneous groups of countries. Subsequently, a regression analysis was conducted for each cluster. Cluster analysis was then used to smooth the differences between the levels of averages for the parameters of the countries studied. In the last stage, a regression analysis was used to evaluate the form and strength of the correlations between banks' nonperforming loans and the soundness of the banks.

Using this method, three country clusters were identified. The linear regression equations were then constructed for each cluster, and for the population as a whole. The greater level of depth of the credit information index and a percentage of private credit bureau coverage led to the smaller share of nonperforming bank loans (Equation 2):

$y=8.049-0.398 \cdot x_{1}-0.016 \cdot x_{2}$,

where, $y$ - nonperforming bank loans to total gross loans (\%); $x_{1}$ - depth of credit information index ( $0=$ low to $8=$ high); $x_{2}$ - private credit bureau coverage ( $\%$ of adults); $a_{0}, a_{1}, a_{2}$-regression parameters.

There was a statistically significant ( $F$-statistics) relation of medium strength, and all parameters of the equation were found to be statistically significant (by a Student $t$-test) when $\alpha=0.05$. At the same time, the direction and power of relation of some clusters did not correlate with the global trend.

The low efficiency of the national system of collecting information about borrowers in Ukraine compared with foreign models was confirmed by the quantitative analysis. This resulted in the high levels of credit risk and low financial stability of domestic banks.

It seems advisable that Ukraine should apply those international models according to which public credit registries operate, while cooperating with private credit bureaus. In particular, private credit bureaus could provide a higher level of detailed information for certain types of credit (mostly loans for small amounts) while providing additional services. The state registers could thus build up a broader base of credit histories. As a result, creditors will be able to accurately assess credit risks, and trust in the credit process as a whole would be improved. 


\section{Concluding remarks}

The present investigations provide several conclusions about EU banking sector and also some findings concerning the Ukraine.

To our mind, restoring trust in EU banks requires fulfilment of the conditions which were investigated in the book (Kovács Levente and Terták Elemér, 2016), among them are: banks' intermediation; regulatory reform; the role of banks and their stakeholders in restoring trust; bankers' self-interest.

Talking about Ukrainian banking sector, on the one hand, analysis of the main policy documents provides evidence that from a strategic point of view, Ukrainian politicians and representatives of financial regulators have made declarations about their strong support of further developments towards enhancing trust in Ukrainian banks.

On the other hand, the quantitative results shown in this paper reflect Ukraine's complicated and scarcely predictable economic and financial development. Without a stable ongoing process of improvement in the macroeconomic situation accompanied by increasing transparency standards, all policy declarations about restoring trust in banks will fail to be reflected in the real social and economic sphere.

Several practical measures could be implemented, however. It would be wise for NBU staff to implement a rule-based approach (with explicit monetary rules) for monetary policy to replace purely discretionary decision-making, which seems entirely subjective from the point of view of outsiders. Furthermore, it is necessary to make active efforts to improve the effectiveness of credit bureaus in Ukraine by establishing a public credit registry. Recently, draft law number 3111 on the establishment of the Credit Registry of the National Bank of Ukraine was revoked. However, the question about the expediency of its introduction in Ukraine continues to be relevant. The last measure would be to maintain the ongoing process of enhancing transparency in the banking system at the NBU level, as well as in commercial banks.

\section{References}

1. Carbó-Valverde, S., Maqui-López, E., Rodríguez-Fernández, F. (2013). Trust in banks: Evidence from the Spanish financial crisis. 26th Australasian Finance and Banking Conference.

2. Gill, A.S., Flaschner, A.B., Shachar, M. (2006). Factors that affect the trust of business clients in their banks. International Journal of Bank Marketing, 24(6), 384-405.

3. Dincer, N., Eichengreen, B. (2013). Central Bank Transparency and Independence: Updates and New Measures. BOK Working Paper. Retrieved from http://media.hotnews.ro/media_server1/document-201309-16-15587972-0-bok-13-21-1.pdf. Accessed on: 03.07.2015.

4. Eijffinger, S.C.W., Geraats, P.M. (2006). How Transparent Are Central Banks? European Journal of Political Economy, 22(1), 1-21.

5. Hyeongwoo, K. (2004): Hodrick-Prescott filter. Retrieved from http://www.auburn.edu/ hzk0001/hpfilter.pdf. Accessed on: 03.06.2012

6. Knell, M., Stix, H. (2009): Trust in banks? Evidence from normal times and from times of crises. The Working Papers 158, published by Österreichische Nationalbank, Vienna.

7. Kovács Levente \& Terták Elemér (2016). Financial Literacy (Panacea or placebo? - A Central European Perspective). Retrieved from http://www.bankszovetseg.hu/wp-content/uploads/2017/01/Financial-literacy-FINAL.pdf. Accessed on: 21.01.2017.

8. Lebedyev, D. (2011). Determinations of trust in banks. Kyiv School of Economics.

9. McCallum, B.T. (1988). Robustness properties of a rule for monetary policy. Carnegie Rochester Conference on Public Policy, 29(1), 173-203.

10. Mosch, R., Prast, H. (2008). Confidence and trust: empirical investigations for the Netherlands and the financial sector. In: DNB Occasional Studies, 6(2), Netherlands Central Bank, Research Department.

11. Mylovanov, T., Gorodnichenko, Y., Zholud, O., Bilan, O. (2016). Should Ukrainians praise the National Bank of Ukraine? Retrieved from http://voxukraine.org/2016/11/28/should-ukrainians-praise-the-national-bank-of-ukraine-en/. Accessed on: 09.12.2016.

12. Narayan, R.K. (1999). The Financial Expert (first published 1952). Published: University of Chicago Press.

13. NBU - National Bank of Ukraine (1999). Law of Ukraine on the National Bank of Ukraine No. 679-XIV of 20 May 1999. Retrieved from https://bank.gov.ua/doccatalog/document?id=47478. Accessed on: 15.11.2016. 
14. NBU - National Bank of Ukraine (2000). Law of Ukraine on banks and banking activity. No. 2121-III of 7 December 2000. Retrieved from https://bank.gov.ua/doccatalog/document?id=47477. Accessed on: 15.11.2016.

15. NBU - National Bank of Ukraine (2015a). Comprehensive program of the Ukrainian financial sector development up to 2020, NBU Board Resolution No. 391 of 18 June 2015. Retrieved from http://www.bank.gov.ua/doccatalog/ document?id=18563297. Accessed on: 07.10.2016.

16. NBU - National Bank of Ukraine (2015b). Monetary policy guidelines for years 2016 - 2020, approved by the Council of the National Bank of Ukraine on September 2015. Retrieved from https://bank.gov.ua/doccatalog/document?id=29187325. Accessed on: 12.10.2016.

17. NBU - National Bank of Ukraine (2016a). Financial stability report, Issue 1. Retrieved from https://bank.gov.ua/ control/uk/publish/category?cat id=32252277. Accessed on: 15.10.2016.

18. NBU - National Bank of Ukraine (2016b). Ukrainian Lending Survey. Retrieved from http://www.bank.gov.ua/ control/en/publish/category;jsessionid=23C2E90CB33227F1 F229E9B98AC9CB57?cat_id =20741795. Accessed on: 07.10.2016.

19. NBU - National Bank of Ukraine (2016c). Business Outlook Survey. Retrieved from https://bank.gov.ua/ control/en/publish/category?cat_id=85948. Accessed on: 12.10.2016.

20. Savchenko, T., Bielova, I. (2016. Impact of credit information on the banks stability: Global experience and lessons for Ukraine. In: Risk Governance \& Control: Financial Markets \& Institutions, 6(2), 28-34.

21. Savchenko, T., Kozmenko, S. (2013). Development of an explicit rule of monetary policy for the economy of Ukraine. Investment Management and Financial Innovations International Research Journal, 10(1), 8-19.

22. Savchenko, T., Kozmenko, S., Piontkovska, Y. (2014). Development and application of the monetary rule for the base interest rate of the National Bank of Ukraine. Banks and Bank Systems, 9(3), 50-58.

23. Savchenko, T., Zakutniaia, A. (2016). Central bank transparency as a condition for effective monetary policy realization. In: Economy \& Finance (English-language Edition of Gazdaság És Pénzügy), 3(3), 234-252.

24. Taylor, J. B. (1999). A historical analysis of monetary policy rules. University of Chicago Press. http://www.nber.org/chapters/c7419 Accessed on: 27.07.2011.

25. Ukraine and the IMF (2016). Letter of intent and memorandum of economic and financial policies. Retrieved from http://www.imf.org/External/NP/LOI/2016/UKR/090116.pdf. Accessed on: 07.10.2016.

26. Ukraine Crisis Media Center (2016). Trust in Ukrainian banks can be restored but it will take years and systematic reforms - experts. Retrieved from http://uacrisis.org/48788-vidnoviti-doviru-ukrayinskihbankiv. Accessed on: 09.11.2016.

\section{Appendix}

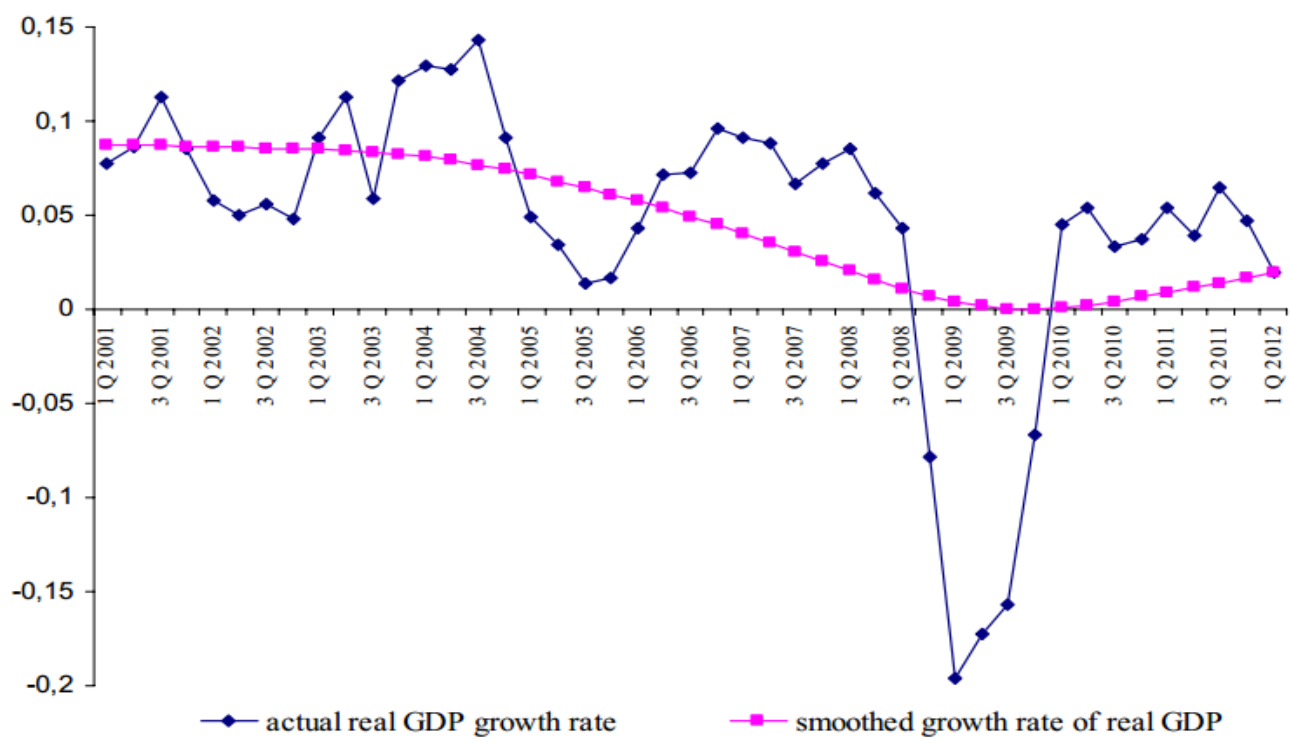

Figure 1. Smooth (trend) component of the quarterly growth rate of real GDP in Ukraine for the period from January 1, 2010 to April 1, 2012, in decimal fractions

Source: compiled by authors. 


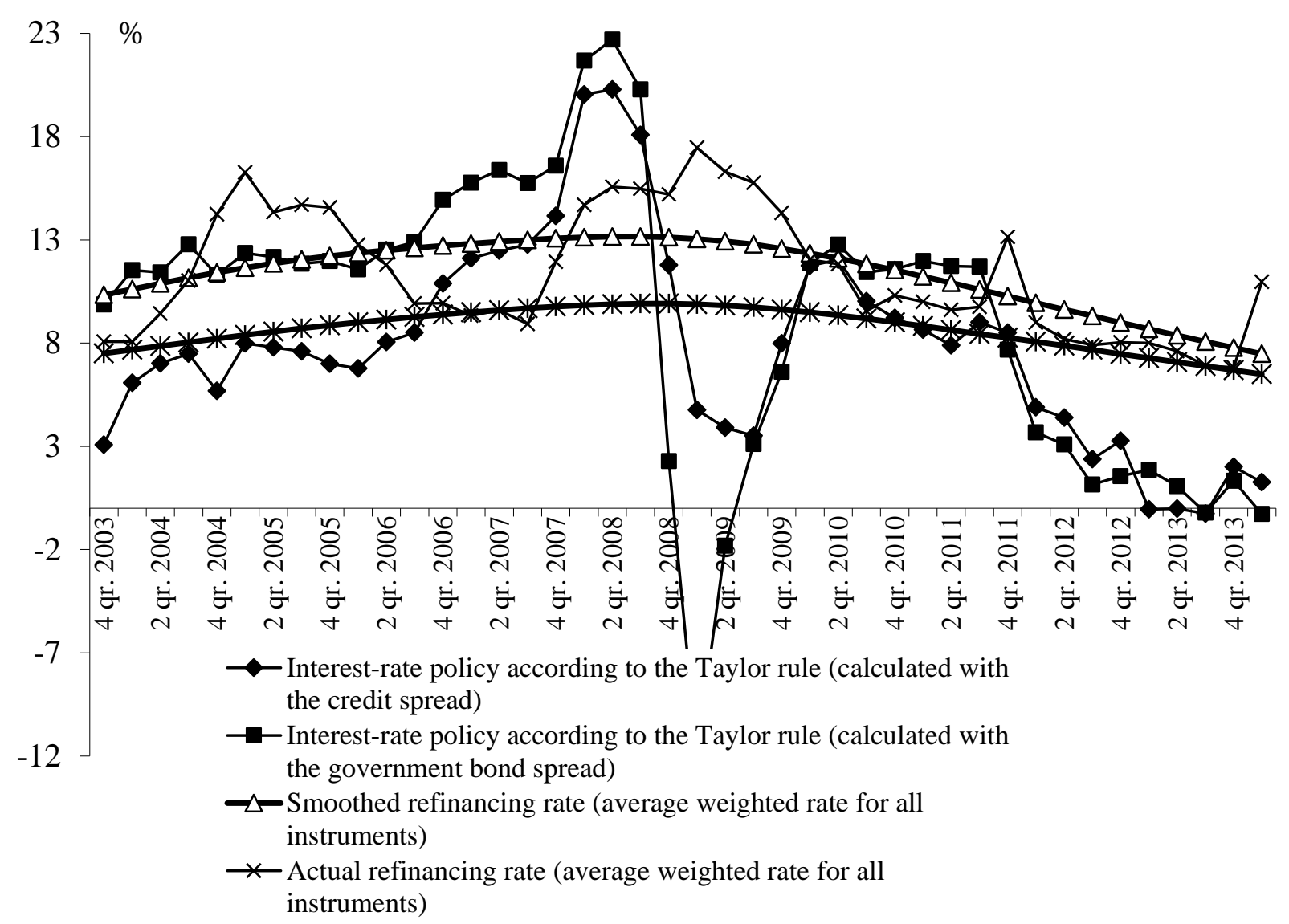

Figure 2. Dynamics of the calculated and actual monetary policy rates of the NBU

Source: compiled by authors. 